\title{
INTENTION TO USE FINGERPRINT SYSTEM IN ELECTRONICS INDUSTRY
}

\author{
Suguna Sinniah ${ }^{1 *}$, Zafir Khan Mohamed Makhbul ${ }^{2}$, Muthaloo Subramaniam ${ }^{3}$, Gopal Perumal ${ }^{4}$, Ramesh Kumar \\ Moona Haji Mohamed ${ }^{5}$ \\ ${ }^{1}$ Graduate School of business, The National University of Malaysia (UKM), Malaysia, ${ }^{2}$ Faculty of Economics and
} Management, the National University of Malaysia (UKM), Malaysia, ${ }^{3,4}$ Faculty of Business, Accounting and Management, SEGi University (SEGi), Malaysia, ${ }^{5}$ Universiti Tunku Abdul Rahman, Malaysia (UTAR). Email: 'suguna@segi.edu.my

Article History: Received on $30^{\text {th }}$ August 2019, Revised on $30^{\text {th }}$ September 2019, Published on $14^{\text {th }}$ October 2019

\begin{abstract}
Purpose: The aim of this study is to assist the Malaysian electronics companies in reducing the non-value added practices and in return, will minimize the cost and improves productivity with the use of the fingerprint system.
\end{abstract}

Methodology: This study uses a quantitative research approach and data were sampled from 137 front-line employees using simple random sampling technique.

Result: The empirical findings of the study confirm that perceived usefulness and perceived ease of use significantly affect the intention to use the fingerprint system. However, there was not enough evidence that relative advantage has any effect on the intention to use the system.

Implications: The study results affirmed that business organizations, especially electronic companies should transform their use of conventional attendance system to fingerprint system in improving efficiencies and effectiveness within the human resource practices.

Keywords: Relative Advantage, Perceived Usefulness, Perceived Ease of Use, Fingerprint system, Non-value added practices.

\section{INTRODUCTION}

In recent days, human resources functions have undergone tremendous changes and the use of evolving technology has made this a reality. The use of technology such as biometric devices in work practices has been very useful (Pankanti, Prabhakar, \& Jain, 2002). A biometric system is a method to recognize an individual based on biological and behavioral characteristics such as fingerprint, vein, palm, iris, voice, and face recognition have been used to identify individuals since time immemorial (Ratha, \& Bolle, 2007; Jain, Ross \& Prabhakar 2004).

In Malaysia, biometrics technology has been widely used by many public sector agencies and the private sector business organizations in improving the safety and quality of their service delivery system. Among the applications, that use of biometric technology is My Kad as national identification documents and Automated Fingerprint Identification System (AFIS) to ascertain the identity of Malaysians through fingerprint detection (Thomas, 2004; O'Gorman \& Chatham, 1999). Biometric technology that uses fingerprints is used for Passport System, Biometrics System for Detection of Illegal Immigrants (PATI) and Biometric Fingerprint Identification System (BIOFIS) to track criminals (John W. Bond, 2009). There are also agencies that use biometrics for access into an office building (Jiang, Zhang, Fu, Liu, \& Su, 2015). This is not new for the private companies in Malaysia that use fingerprints system in improving the safety and quality of their human resource management practices. Increasingly, countless firms use the fingerprint attendance system compare to the classic time registration system (based on pin codes or badges) which carries problems to them (Ogbanufe \& Kim, 2018; Ratha, \& Bolle, 2007). There are a number of problems and weaknesses of the present system are still used in most of the companies. Lee, Ramotowski, \& Gaensslen (2001) affirmed that manager or supervisor should call the name of each employee workers to record their presence and this consumes a lot of time and affects the productive hours which otherwise could be used for better means.

\section{LITERATURE REVIEW}

Numerous researchers have identified the determinants of adopting biometrics. (Byun \& Byun, 2013; Lancelot Miltgen, Popovič, \& Oliveira, 2013; Soh, Wongand, \& Chan, 2010; James, Pirim, \& Boswell, 2006) suggested that the purpose to use the system is depending on factors of effectiveness, user-friendliness, threat, and benefits. There has Review of literature applied Rogers's (1995) Theory of Diffusion of Innovation and Technology Adoption Model (TAM) proposed by Davis, Bagozzi and Warshaw's (1989) to establish the relationship between the variables and the usage of fingerprint system. These variables are relative advantage, perceived usefulness and perceived ease of use.

\section{Relative advantages}

The relative advantage is known as a great predictor of the role of innovation (Rogers, 2015; Agarwal, 2000). (Davis, Bagozzi, and Warshaw, 1989)defined relative advantage as the degree of innovation which seen as better than the ideas that substitute. It can also be expressed as what would be the cost and what will be the benefits of innovation (Moore, \& Benbasat, 1991; Mattila, 2015).Relative advantages including user-friendly, low initial cost, comfort, time-efficient, fewer 
errors, improve service, and the ability to provide sufficient data and immediacy of the reward. Fingerprint system can systematize management task, reduce paperwork, simplify processes and distributes the necessary information to top management, thereby it increases the effectiveness of the human resource management practices (Ogbanufe \& Kim, 2018; Arif, Li, \& Cheng, 2017; Jiang et al., 2015). It also helps the organization to save time in gathering information about the worker's arrivals and strategic planning. Therefore, this research hypothesizes that relative advantages would positively affect the intention to use fingerprint system.

$\mathbf{H}_{\mathbf{1}}$ : Perceived usefulness would positively influence the intention to use fingerprint system in Human Resources Management practices.

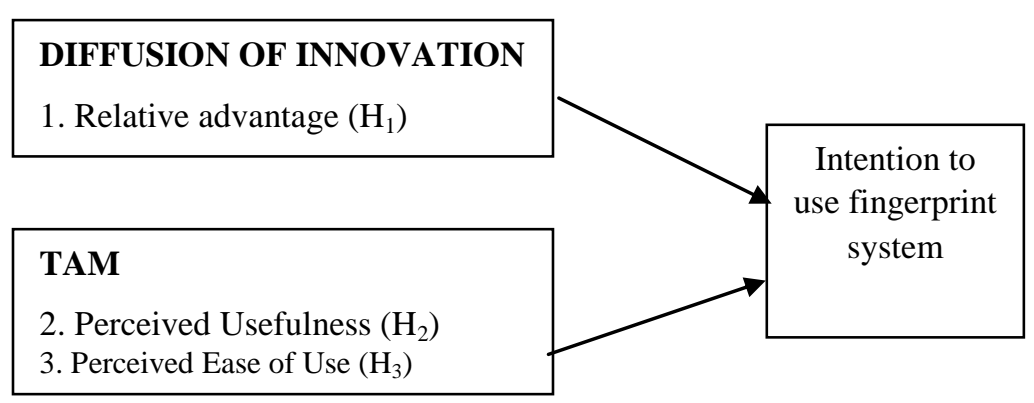

Figure 1: Conceptual Framework

\section{Perceived Usefulness}

Perceived usefulness is known as which a person believes that it will enhance their performance by using a particular system (Davis, 1989). In the organizational context, employees are normally reinforced by a noble performance by increments, bonuses, promotions and other rewards (Dooley, 2011; Vroom, 1964). Any system which is categorized as high in perceived usefulness turns to be one of the user's strength who believes in the existence of a positive userperformance relationship (Davis, 1989). There are several types of research has been done in various industries such as hospital, pharmaceutical, food and beverage, hotels and etc. its shows that, perceived usefulness significantly influence the intention to use fingerprint system (Alalwan, Dwivedi, Rana, \& Williams, 2016; Ogbanufe \& Kim, 2018; Lian \&Tui, 2012; James et al., 2006). Although past literature contributed to global human development, it will be beneficial to study the use of fingerprint system among manufacturing industries in Malaysia. Therefore this research also hypothesizes that perceived usefulness would positively influence intention to use fingerprint system.

$\mathbf{H}_{2}$ : Perceived usefulness would positively influence the intention to use the fingerprint system in Human Resources Management practices.

\section{Perceived Ease of Use}

Perceived ease of use is defined as a level of a personal consideration of using a system that can reduce one's effort in doing something (Hamid, Razak, Bakar, \& Abdullah, 2016). The ease of use perspective is able to convince the user that the information technology to be applied is an easy thing and not a burden to them. All users seem to accept the usage of an application which perceived to be easier and its supported by past studies which (Hamid, Razak, Bakar, \& Abdullah, 2016; Kucukusta, Law, Besbes, \& Legohérel, 2015; Hernandez \& Mazzon, 2007; Guriting \& Oly Ndubisi, 2006; Eriksson, Kerem, \& Nilsson, 2005; Wang, Wang, Lin, \& Tang, 2003; Venkatesh,2000; McGrath, Tsai, Venkataraman, \& MacMillan, 1996; M. Igbaria \& Iivari, 1995). However, the findings of (Magid Igbaria, Zinatelli, Cragg, \& Cavaye, 1997; Davis, 1989) found that perceived ease of use has no impact on the usage and adoption of the technology. Regulatory of the usage and interaction between the system handlers is also show the ease of use. The more the usage of the system, it is easier to operate, and be the mastered of it. The results of this study show that this factor is proven empirically, can explain the reasons the end-user in using the information system and explain that the new system which was then being developed, accepted by end-user users. Therefore this research hypothesizes that perceived ease of use would positively influence the use of the fingerprint system.

$\mathbf{H}_{3}$ : Perceived ease of use would positively influence the intention to use the fingerprint system in Human Resources Management practices.

\section{RESEARCH METHODOLOGY}

The research was conducted with employees at one of the electronic companies in Penang (Malaysia), especially front-line employees which refers to non-managerial employees who perform according to the instructions by supervisor and division managers. The estimated population for this research is 11,200 employees (Department of Statistic Malaysia 2012). According to Raosof sample size calculator, 400 sample sizes were recommended as a sample size. Out of 400 distributed questionnaires, researcher successfully collected only 137 completed questionnaires. The distributed questionnaire consists of total of three sections with Likert scale ratings. The questionnaire was adapted by previous research and designed to accommodate this research. 


\section{RESULTS/FINDINGS}

\section{Testing Methods}

The structural equation modeling (SEM-PLS) approach was used in this research to examine the level of significance (Ramayah, Yeap, and Ignatius, 2013). A measurement model and the structural model been obtained to complete this research (Anderson and Gerbing, 1988). Common bias method is negligible in this study due to $70 \%$ of total variance. To get the assumption for data normality Shapiro-Wilk and Kolmogorov been conducted Based on Park (2015). The researcher will be able to conclude the test if outcome as non-significant ( $>0.05)$, which shows the normal distribution. Next, the technique if outlier detection which is known as anomaly decision was used to identify the unusual patterns that do not conform to expected behavior (Choudhary \& Nagaraja, 2017).

\section{Descriptive Analysis}

Table 1: Demographic profile of the respondents

\begin{tabular}{|c|c|c|c|c|c|}
\hline & & Frequency & Percent & Valid Percent & $\begin{array}{l}\text { Cumulative } \\
\text { Percent }\end{array}$ \\
\hline \multirow[t]{3}{*}{ Gender } & Male & 37 & 27.0 & 27.0 & 27.0 \\
\hline & Male & 100 & 73.0 & 73.0 & 100.0 \\
\hline & Total & 137 & 100.0 & 100.0 & \\
\hline \multirow[t]{5}{*}{ Age Group } & 18 to 30 years & 39 & 28.5 & 28.5 & 28.5 \\
\hline & 31 to 40 years & 52 & 38.0 & 38.0 & 66.4 \\
\hline & 41 to 50 years & 36 & 26.3 & 26.3 & 92.7 \\
\hline & Above 50 years & 10 & 7.3 & 7.3 & 100.0 \\
\hline & Total & 137 & 100.0 & 100.0 & \\
\hline \multirow[t]{5}{*}{ Race } & Malay & 116 & 84.7 & 84.7 & 84.7 \\
\hline & Chinese & 13 & 9.5 & 9.5 & 94.2 \\
\hline & India & 3 & 2.2 & 2.2 & 96.4 \\
\hline & Others & 5 & 3.6 & 3.6 & 100.0 \\
\hline & $\overline{\text { Total }}$ & 137 & 100.0 & 100.0 & \\
\hline \multirow[t]{3}{*}{ Marital Status } & Married & 103 & 75.2 & 75.2 & 75.2 \\
\hline & Unmarried & 34 & 24.8 & 24.8 & 100.0 \\
\hline & Total & 137 & 100.0 & 100.0 & \\
\hline \multirow[t]{4}{*}{ Education } & Bachelors and Above & 11 & 8.0 & 8.0 & 8.0 \\
\hline & STPM/Diploma & 28 & 20.4 & 20.4 & 28.5 \\
\hline & SPM and Below & 98 & 71.5 & 71.5 & 100.0 \\
\hline & Total & 137 & 100.0 & 100.0 & \\
\hline
\end{tabular}

\section{Measurement Model}

Firstly, reliability, convergent validity, and discriminant validity were tested before testing hypothesized model (Silaparasetti, Srinivasarao \& Khan, 2017). All loading which shown in table 2, was higher than 0.70 which threshold (Hair, Hult, Ringle, and Sarstedt, 2016).The convergent validity is achieved with higher composite reliability and average variance extracted (AVE).

Table 2: Convergent validity

\begin{tabular}{|c|c|c|c|c|c|c|c|}
\hline No & Items & Loadings & Cronbach's Alpha & rho_A & $\mathbf{C R}$ & AVE & VIF \\
\hline 1 & IT1 & 0.813 & 0.86 & 0.861 & 0.899 & 0.641 & 2.193 \\
\hline 2 & IT2 & 0.798 & & & & & 2.151 \\
\hline 3 & IT3 & 0.816 & & & & & 2.065 \\
\hline 4 & IT4 & 0.789 & & & & & 2.059 \\
\hline 5 & IT5 & 0.787 & & & & & 1.95 \\
\hline 6 & PEU1 & 0.902 & 0.886 & 0.89 & 0.917 & 0.688 & 3.329 \\
\hline 7 & PEU2 & 0.854 & & & & & 2.484 \\
\hline 8 & PEU3 & 0.818 & & & & & 2.267 \\
\hline 9 & PEU4 & 0.75 & & & & & 1.745 \\
\hline 10 & PEU5 & 0.816 & & & & & 2.099 \\
\hline
\end{tabular}




\begin{tabular}{llllllll}
\hline 11 & PU1 & 0.725 & 0.879 & 0.88 & 0.912 & 0.676 & 1.489 \\
\hline 12 & PU2 & 0.849 & & & & & 2.516 \\
\hline 13 & PU3 & 0.884 & & & & & \\
\hline 14 & PU4 & 0.84 & & & & & \\
\hline 15 & PU5 & 0.803 & 0.203 \\
\hline 16 & RA1 & 0.901 & 0.874 & 0.879 & 0.923 & 0.799 & 2.248 \\
\hline 17 & RA2 & 0.92 & & & & & 2.562 \\
\hline 18 & RA3 & 0.86 & & & & 2.064 \\
\hline
\end{tabular}

Table 3 shows that all constructs have discriminant validity. To indicate sufficient discriminant validity, all loadings of measured variables should be higher than the cross-loadings by at least 0.1 (Hair et al. (2016). Multicollinearity is examined in Table 2. VIF below the range of 3.3 shows, all constructs confirm that the construct validity is sufficient which falls below the minimum threshold of 9 (Yong \& Pearce, 2013).

Table 3: Discriminant validity of the construct

\begin{tabular}{lllll}
\hline Construct & IT & PEU & PU & RA \\
\hline IT & $\mathbf{0 . 8 0 1}$ & & & \\
\hline PEU & 0.584 & $\mathbf{0 . 8 3}$ & & \\
\hline PU & 0.617 & 0.737 & $\mathbf{0 . 8 2 2}$ & $\mathbf{0 . 8 9 4}$ \\
\hline RA & 0.408 & 0.547 & 0.539 & \\
\hline
\end{tabular}

Note $=\mathrm{IT}=$ Intention to use, $\mathrm{PEU}=$ Perceived ease of use, $\mathrm{PU}=$ Perceived usefulness, $\mathrm{RA}=$ Relative advantage

Table 4: Cross Loadings

\begin{tabular}{lllll}
\hline Items & IT & PEU & PU & RA \\
\hline IT1 & $\mathbf{0 . 8 1 3}$ & 0.5 & 0.542 & 0.297 \\
\hline IT2 & $\mathbf{0 . 7 9 8}$ & 0.51 & 0.463 & 0.274 \\
\hline IT3 & $\mathbf{0 . 8 1 6}$ & 0.464 & 0.472 & 0.314 \\
\hline IT4 & $\mathbf{0 . 7 8 9}$ & 0.464 & 0.494 & 0.387 \\
\hline IT5 & $\mathbf{0 . 7 8 7}$ & 0.394 & 0.494 & 0.365 \\
\hline PEU1 & 0.49 & $\mathbf{0 . 9 0 2}$ & 0.642 & 0.572 \\
\hline PEU2 & 0.525 & $\mathbf{0 . 8 5 4}$ & 0.654 & 0.405 \\
\hline PEU3 & 0.483 & $\mathbf{0 . 8 1 8}$ & 0.603 & 0.456 \\
\hline PEU4 & 0.538 & $\mathbf{0 . 7 5}$ & 0.531 & 0.373 \\
\hline PEU5 & 0.386 & $\mathbf{0 . 8 1 6}$ & 0.622 & 0.452 \\
\hline PU1 & 0.516 & 0.668 & $\mathbf{0 . 7 2 5}$ & 0.391 \\
\hline PU2 & 0.488 & 0.596 & $\mathbf{0 . 8 4 9}$ & 0.503 \\
\hline PU3 & 0.557 & 0.603 & $\mathbf{0 . 8 8 4}$ & 0.487 \\
\hline PU4 & 0.515 & 0.612 & $\mathbf{0 . 8 4}$ & 0.418 \\
\hline PU5 & 0.443 & 0.531 & $\mathbf{0 . 8 0 3}$ & 0.408 \\
\hline RA1 & 0.36 & 0.503 & 0.492 & $\mathbf{0 . 9 0 1}$ \\
\hline RA2 & 0.401 & 0.513 & 0.495 & $\mathbf{0 . 9 2}$ \\
\hline RA3 & 0.33 & 0.45 & 0.457 & $\mathbf{0 . 8 6}$ \\
\hline
\end{tabular}

Note $=$ IT $=$ Intention to use, $\mathrm{PEU}=$ Perceived ease of use, $\mathrm{PU}=$ Perceived usefulness, $\mathrm{RA}=$ Relative advantage

This study has tested the discriminant validity and the results are shown in Table 5. To assess the discriminant validity two methods were used which is (1) as the criterion and (2) as a statistical test. The HTMT value is greater than 0.85 (Kline 2015), and 0.90(Gold \& Arvind Malhotra, 2001). This study follows the guideline of Henseler et al. (2016) to assess the measurement model. This study shows that there is a problem of discriminate validity.

Table 5: Heterotrait-Monotrait (HTMT)

\begin{tabular}{|c|c|c|c|c|c|}
\hline Construct & Intention & PEU & $\mathbf{P U}$ & $\mathbf{R A}$ & Saturated Model \\
\hline IT & & & & SRMR & 0.067 \\
\hline PEU & 0.668 & & & d_ULS & 0.773 \\
\hline
\end{tabular}




\begin{tabular}{llllll}
\hline PU & 0.705 & 0.832 & & d_G1 & 0.53 \\
\hline RA & 0.47 & 0.619 & 0.613 & & \\
\hline
\end{tabular}

Note $=$ IT $=$ Intention to use, $\mathrm{PEU}=$ Perceived ease of use, $\mathrm{PU}=$ Perceived usefulness, $\mathrm{RA}=$ Relative advantage

Table 5 shows, $0.53 \mathrm{dG}, 0.773 \mathrm{dULS}$ and 0.067 SRMR which lesser than the off of 0.08 ( $\mathrm{Hu} \&$ Bentler, 1999) which fits well the measurement model.

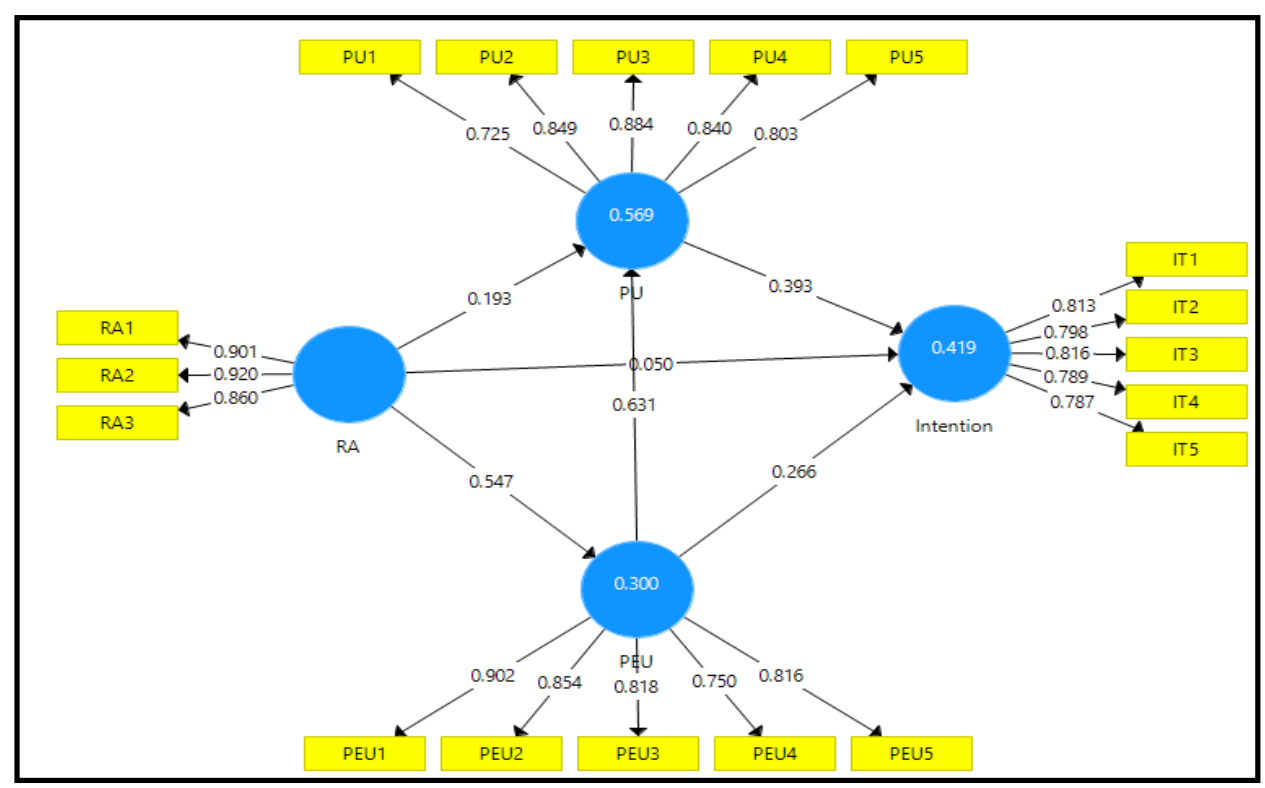

Figure 2: Measurement Model

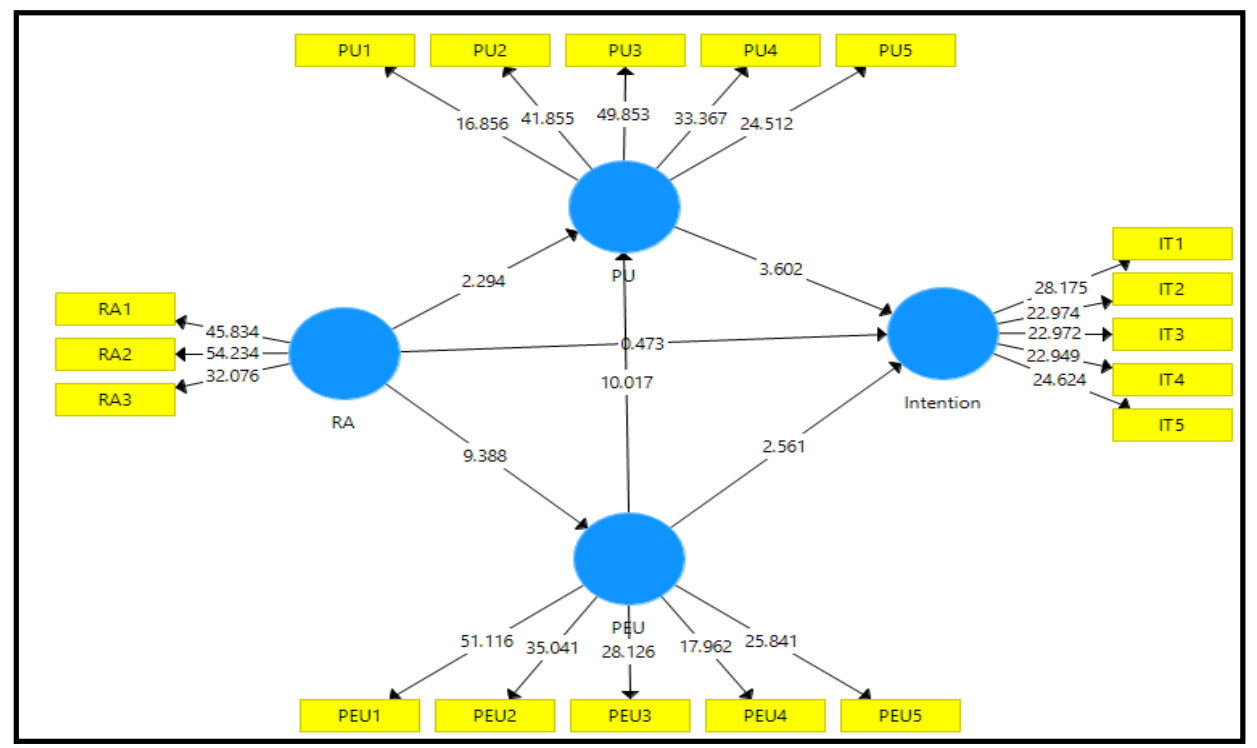

Fig. 3: Structural model

Table 6: Hypothesis results

\begin{tabular}{lllllllllll}
\hline Hypothesis & & & & & & & & & $\mathbf{Q}^{2}$ & $(=1-$ \\
SSE/SSO) & Decision \\
\hline & & Std Err & T Value & P Values & LL & UL & f2 & r2 & & \\
$\mathbf{H}_{\mathbf{1}}$ & 0.05 & 0.106 & 0.473 & 0.636 & -0.161 & 0.26 & 0.003 & & 0.352 & Sot \\
\hline $\mathbf{H}_{\mathbf{2}}$ & 0.393 & 0.109 & 3.602 & 0.000 & 0.16 & 0.585 & 0.115 & & 0.187 & Supported \\
\hline $\mathbf{H}_{\mathbf{3}}$ & 0.266 & 0.104 & 2.561 & 0.010 & 0.065 & 0.474 & 0.052 & 0.419 & 0.239 & Supported \\
\hline
\end{tabular}

Note $=$ IT $=$ Intention to use, $\mathrm{PEU}=$ Perceived ease of use, $\mathrm{PU}=$ Perceived usefulness, RA= Relative advantage

Figure 2 presents a structural model that shows all path coefficients and their corresponding t-values as well as the explanatory power of the estimated model. Meanwhile Table 6 presents the outcomes of the hypothesis testing. The 
multiple regression analysis models were significant $(\mathrm{p}, 0.01)$ and the coefficients show, 0.419 , which indicates that $41.9 \%$ percent of the variation in intention to use. Thus, $\mathrm{H} 2$ and H3, were supported as shown in Table $6, \mathrm{H} 1(\beta=0.05, \mathrm{p}<0.05)$, $\mathrm{H} 2(\beta=0.393, \mathrm{p}<0.05), \mathrm{H} 3(\beta=0.266, \mathrm{p}<0.05)$. Thus, the study concludes that H2, and H3 was supported except H1 $(\beta=$ $0.05, \mathrm{p}>0.05)$.

\section{DISCUSSION}

The result of $\operatorname{Pr}>\mathrm{F}$ in the multiple regression analysis is $<0.0001$. It shows out of three independent variables, two variables have significant relationship with dependent variable. In addition, the R-square is 0.419 , which indicates that 41.9 percent of the variance in the dependent variable (intention to use) is explained by the three independent variables (relative advantage, perceived ease of use and perceived usefulness).

Based on the result, relative advantage has pointed out the greatest contribution to the variation of the dependent variable (intention to use) with the highest value of beta which is 0.065 compared to other independent variables. Besides that, perceived usefulness and perceived ease of use showed the least contribution to the variation of the dependent variable (intention to use) with the lowest value of beta this is 0.000 . Furthermore, both of the independent variables (Compatibility, Complexity) are found significantly to predict the dependent variable (Behavioral intention) with the beta of 0.010 and 0.000 respectively. Based on these findings, the researcher would like to conclude that human resource management practices have significant positive relationship with behavioral intention. It shows that, when human capital practices are good, the behavioral intention will be higher in an organization.

\section{CONCLUSION}

Thus, the findings from this study are very crucial for the management of the electronic industry to understand behavioral intention. Besides, this study also explored how employees perceive importance of human resource management practices such as relative advantage, perceived ease of use and perceived usefulness, Human resources management practices are the essential tools that had been used by the organization nowadays for stimulating their strategic management by using fingerprint system. The main purposes of human resource management practices are to motivate, attract and retain employees. Effective human resources management practices such as fingerprint system will obtain quality employees and it also will motivate them to improve their job performance and helps them to meet their psychological needs and social needs (Kepha, 2015).Therefore, innovative human resource management practices will increase employee's commitment and help them to achieve organization's goals. The more satisfaction of employees with human resources management practices, the more commitment of employees toward the organization (Kumar \& Krishnaveni, 2008).

\section{REFERENCES}

1. Agarwal, R. (2000). Individual Acceptance of Information Technologies. Educational Technology Research and Development. https://doi.org/10.1175/1520-0442(2001)014<2266:MOITDV>2.0.CO;2

2. Alalwan, A. A., Dwivedi, Y. K., Rana, N. P. P., \& Williams, M. D. (2016). Consumer adoption of mobile banking in Jordan: Examining the role of usefulness, ease of use, perceived risk and self-efficacy. Journal of Enterprise Information Management. https://doi.org/10.1108/JEIM-04-2015-0035

3. Anderson, J. C., \& Gerbing, D. W. (1988). Structural Equation Modeling in Practice: A Review and Recommended Two-Step Approach. Psychological Bulletin. https://doi.org/10.1037//0033-2909.103.3.411

4. Arif, A., Li, T., \& Cheng, C. H. (2017). Blurred fingerprint image enhancement: algorithm analysis and performance evaluation. Signal, Image and Video Processing. https://doi.org/10.1007/s11760-017-1218-0

5. Bagozzi, R. P., \& Yi, Y. (1988). On the evaluation of structural equation models. Journal of the academy of marketing science, 16(1), 74-94. https://doi.org/10.1007/BF02723327

6. Byun, S., \& Byun, S. E. (2013). Exploring perceptions toward biometric technology in service encounters: A comparison of current users and potential adopters. Behaviour and Information Technology. https://doi.org/10.1080/0144929X.2011.553741

7. Chew, J., \& Chan, C. C. (2008). Human resource practices, organizational commitment and intention to stay. International journal of manpower, 29(6), 503-522.Davis, F. D. (1989). Perceived Usefulness, Perceived Ease of Use, and User Acceptance of Information Technology. MIS Quarterly. https://doi.org/10.2307/249008

8. Choudhary, P. K., \& Nagaraja, H. N. (2017). Measuring Agreement: Models, Methods, and Applications (Vol. 891). John Wiley \& Sons. https://doi.org/10.1002/9781118553282

9. Davis, F. D. (1989). Perceived usefulness, perceived ease of use, and user acceptance of information technology. MIS quarterly, 319-340. https://doi.org/10.2307/249008

10. Davis, F.D, Bagozzi, R. P., Warshaw, P, R. (1989). "Use acceptance of computer technology: A comparison of two theoretical models", Management Science, 35, 982 - 1003. https://doi.org/10.1287/mnsc.35.8.982

11. Dijkstra, T. K., \& Henseler, J. (2015). Consistent Partial Least Squares Path Modeling. MIS quarterly, 39(2). https://doi.org/10.25300/MISQ/2015/39.2.02

12. Dooley, K. J. (2011). Organizational psychology. In Chaos and Complexity in Psychology: The Theory of Nonlinear Dynamical Systems. https://doi.org/10.1017/CBO9781139058544.015 
13. Eriksson, K., Kerem, K., \& Nilsson, D. (2005). Customer acceptance of internet banking in Estonia. International Journal of Bank Marketing. https://doi.org/10.1108/02652320510584412Field, A. (2005). Discovering Statistics Using SPSS. London: Sage Publications. https://doi.org/10.1108/02652320510584412

14. Fornell, C., \& Larcker, D.F. (1981). Evaluating Structural Equation Models with Unobservable Variables and Measurement Error. Journal of Marketing Research, 18, 39 -50. https://doi.org/10.1177/002224378101800104

15. Guriting, P., \& Oly Ndubisi, N. (2006). Borneo online banking: Evaluating customer perceptions and behavioural intention. Management Research News. https://doi.org/10.1108/01409170610645402

16. Gold, A. H., Malhotra, A., \& Segars, A. H. (2001). Knowledge management: An organizational capabilities perspective. Journal of Management Information Systems. https://doi.org/10.1080/07421222.2001.11045669

17. Hair J. F., Hult, G. T. M., Ringle, C., \& Sarstedt, M. (2016). A primer on partial least squares structural equation modeling (PLS-SEM). Sage Publications, Thousand Oaks.

18. Hair, J. F. (2007). Research methods for business.

19. Hair, J. F. Jr., Money, A.H., Samouel, P., \& Page, M. (2007). Research methods for business. Chichester, West Sussex: John Wilet \& Sons, Inc.

20. Henseler, J., Hubona, G., \& Ray, P. A. (2016). Using PLS path modeling in new technology research: updated guidelines. Industrial management \& data systems, 116(1), 2-20. https://doi.org/10.1108/IMDS-09-2015-0382

21. Henseler, J., Ringle, C. M., \& Sarstedt, M. (2015). A new criterion for assessing discriminant validity in variancebased structural equation modeling. Journal of the Academy of Marketing Science,43(1), 115-135. https://doi.org/10.1007/s11747-014-0403-8

22. Hernandez, J. M. C., \& Mazzon, J. A. (2007). Adoption of internet banking: proposition and implementation of an integrated methodology approach. International Journal of Bank Marketing. https://doi.org/10.1108/02652320710728410

23. Hoelter, J. W. (1983). The analysis of covariance structures: Goodness-of-fit indices. Sociological Methods and Research, 11, 325-344. https://doi.org/10.1177/0049124183011003003

24. Hu, L. T., \& Bentler, P. M. (1999). Cutoff criteria for fit indexes in covariance structure analysis: Conventional criteria versus new alternatives. Structural equation modeling: a multidisciplinary journal,6(1), 1-55. https://doi.org/10.1080/10705519909540118

25. Hamid, A. A., Razak, F. Z. A., Bakar, A. A., \& Abdullah, W. S. W. (2016). The Effects of Perceived Usefulness and Perceived Ease of Use on Continuance Intention to Use E-Government. Procedia Economics and Finance. https://doi.org/10.1016/S2212-5671(16)00079-4

26. Igbaria, M., \& Iivari, J. (1995). The effects of self-efficacy on computer usage. Omega. https://doi.org/10.1016/0305-0483(95)00035-6

27. Igbaria, M., Zinatelli, N., Cragg, P., \& Cavaye, A. L. M. (1997). Personal Computing Acceptance Factors in Small Firms: A Structural Equation Model. MIS Quarterly. https://doi.org/10.2307/249498

28. James, T., Pirim, T., \& Boswell, K. (2006). Determining the intention to use biometric devices: An application and extension of the technology acceptance model. Journal of Organizational and End User Computing. https://doi.org/10.4018/9781599042954.ch005

29. Jain, A. K., Ross, A., \& Prabhakar, S. (2004). An introduction to biometric recognition. IEEE Transactions on circuits and systems for video technology, 14(1), 4-20. https://doi.org/10.1109/TCSVT.2003.818349

30. Jiang, P., Zhang, Y., Fu, W., Liu, H., \& Su, X. (2015). Indoor mobile localization based on Wi-Fi fingerprint's important access point. International Journal of Distributed Sensor Networks. https://doi.org/10.1155/2015/429104

31. John W. Bond. (2009). The value of fingerprint evidence in detecting crime. International Journal of Police Science \& Management, 11(1), 77-84. https://doi.org/10.1350/ijps.2009.11.1.111

32. Johnson, S. M., Kraft, M. A., \& Papay, J. P. (2012). How context matters in high-need schools: The effects of teachers' working conditions on their professional satisfaction and their students' achievement. Teachers College Record, 114(10), 1-39.

33. Kepha, A. O. (2015). Influence of Human Resource Management Practices on the Performance of Employees in Research Institutes in Kenya (Doctoral dissertation).

34. Kline, R.B. (2015). Principles and practice of structural equation modeling (4th ed.). New York: Guilford Publications.

35. Kumar, N.R. \& Krishnaveni, R. (2008). Role of HRD practices in building organizational commitment, Journal of Contemporary Research in Management, April-June, 59-68.

36. Kucukusta, D., Law, R., Besbes, A., \& Legohérel, P. (2015). Re-examining perceived usefulness and ease of use in online booking the case of Hong Kong online users. International Journal of Contemporary Hospitality Management. https://doi.org/10.1108/IJCHM-09-2013-0413

37. Lancelot Miltgen, C., Popovič, A., \& Oliveira, T. (2013). Determinants of end-user acceptance of biometrics: Integrating the "big 3" of technology acceptance with privacy context. Decision Support Systems. https://doi.org/10.1016/j.dss.2013.05.010

38. Lee, H. C., Ramotowski, R., \& Gaensslen, R. E. (Eds.). (2001). Advances in fingerprint technology. CRC press.

39. Lian, L. K., \& Tui, L. G. (2012). The mediating effect of downward influence tactics on the relationship between leadership style and organizational citizenship behavior. Jurnal Pengurusan. 
40. Mattila, M. (2015). Factors affecting the adoption of mobile banking services. The Journal of Internet Banking and Commerce, 2003.

41. McEvoy, T. G., Robinson, J. J., Aitken, R. P., Findlay, P. A., \& Robertson, I. S. (1997). Dietary excesses of urea influence the viability and metabolism of preimplantation sheep embryos and may affect fetal growth among survivors. Animal reproduction science, 47(1), 71-90. https://doi.org/10.1016/S0378-4320(96)01627-2

42. McGrath, R. G., Tsai, M.-H., Venkataraman, S., \& MacMillan, I. C. (1996). Innovation, Competitive Advantage and Rent: A Model and Test. Management Science, 42(3), 389-403. https://doi.org/10.1287/mnsc.42.3.389. https://doi.org/10.1287/mnsc.42.3.389

43. Moore, G. C., \& Benbasat, I. (1991). Development of an instrument to measure the perceptions of adopting an information technology innovation. Information systems research,2(3), $192-222$. https://doi.org/10.1287/isre.2.3.192

44. O’Gorman, L., \& Chatham, N. J. (1999). 2 Fingerprint Verification. Personal Identification in Networked Society. https://doi.org/10.1007/978-0-387-32659-7

45. O'Hair, D., Friedrich, G. W., \& Dixon, L. D. (2007). Strategic communication in business and the professions. Allyn \& Bacon.

46. Ogbanufe, O., \& Kim, D. J. (2018). Comparing fingerprint-based biometrics authentication versus traditional authentication methods for e-payment. Decision Support Systems. https://doi.org/10.1016/j.dss.2017.11.003

47. Pankanti, S., Prabhakar, S., \& Jain, A. K. (2002). On the individuality of fingerprints. IEEE Transactions on Pattern Analysis and Machine Intelligence. https://doi.org/10.1109/TPAMI.2002.1023799

48. Park, H. M. (2015). Univariate analysis and normality test using SAS, Stata, and SPSS

49. Paul, A. K., \& Anantharaman, R. N. (2004). Influence of HRM practices on organizational commitment: A study among software professionals in India.Human Resource Development Quarterly, 15(1), 77-88. https://doi.org/10.1002/hrdq.1088

50. Podsakoff, P.M., \& Organ, D.W. (1986). "Self-reports in organizational research: Problems and prospects " Journal of Management, 12(4), 531-544. https://doi.org/10.1177/014920638601200408

51. Podsakoff, P.M., MacKenzie, S.B., Lee, J.-Y., \& Podsakoff, N.P. (2003) "Common methods biases in behavioral research: a critical review of the literature and recommended remedies," Journal of Applied Psychology 88(5), 879-903. https://doi.org/10.1037/0021-9010.88.5.879

52. Porter, M. E. (1985). Technology and competitive advantage. Journal of business strategy, 5(3), $60-78$. https://doi.org/10.1108/eb039075

53. Preacher, K.J., \& Hayes, A.F. (2008). Asymptotic and resampling strategies for assessing and comparing indirect effects in multiple mediator models. Behavior Research Methods, 40(3), 879-891. https://doi.org/10.3758/BRM.40.3.879

54. Ramayah, T., Yeap, J. A. L., \& Ignatius, J. (2013). An Empirical Inquiry on Knowledge Sharing Among Academicians in Higher Learning Institutions. Minerva. https://doi.org/10.1007/s11024-013-9229-7

55. Ratha, N., \& Bolle, R. (Eds.). (2007). Automatic fingerprint recognition systems. Springer Science \& Business Media.

56. Rogers, E. M. (1995). Diffusion of Innovations-Fourth Edition. Everett M. Rogers. https://doi.org/citeulikearticle- id: 126680

57. Rogers, E. M. (2015). Evolution: Diffusion of Innovations. In International Encyclopedia of the Social \& Behavioral Sciences: Second Edition. https://doi.org/10.1016/B978-0-08-097086-8.81064-8

58. Sekaran, U., \& Bougie, R. (2010). Theoretical framework In theoretical framework and hypothesis development. Research Methods for Business: A Skill Building Approach, United Kingdom: Wiley, 80.

59. Silaparasetti, V., Srinivasarao, G. V. R., \& Khan, F. R. (2017). Structural Equation Modeling Analysis Using Smart Pls To Assess The Occupational Health And Safety (Ohs) Factors On Workers'behavior. Humanities \& Social Sciences Reviews, 5(2), 88-97. https://doi.org/10.18510/hssr.2017.524

60. Soh, K. L., Wongand, W. P., \& Chan, K. L. (2010). Adoption of biometric technology in online applications. International Journal of Business and Management Science.

61. Teo, T. S., Lim, G. S., \& Fedric, S. A. (2007). The adoption and diffusion of human resources information systems in Singapore. Asia Pacific Journal of Human Resources, 45(1), 44-62. https://doi.org/10.1177/1038411107075402

62. Thomas, M. (2004). Is Malaysia's Mykad the One Card to Rule Them All-The Urgent Need to Develop a Proper Legal Framework for the Protection of Personal Information in Malaysia. Melb. UL Rev., 28, 474.

63. Thompson, R. L., Higgins, C. A., \& Howell, J. M. (1991). Personal computing: toward a conceptual model of utilization. MIS quarterly, 125-143. https://doi.org/10.2307/249443

64. Venkatesh, V. (2000). Determinants of Perceived Ease of Use: Integrating Control, Intrinsic Motivation, and Emotion into the Technology Acceptance Model. Information Systems Research. https://doi.org/10.1287/isre.11.4.342.11872.

65. Vroom, V. H. (1964). Work and motivation. John Wiley and Sons. https://doi.org/10.1016/j.biortech.2014.02.116

66. Wang, Y. S., Wang, Y. M., Lin, H. H., \& Tang, T. I. (2003). Determinants of user acceptance of Internet banking: An empirical study. In International Journal of Service Industry Management. https://doi.org/10.1108/09564230310500192 
67. Weiers, R. M. (2008). Introduction to Statistics.

68. Yong, A. G., \& Pearce, S. (2013). A beginner's guide to factor analysis: Focusing on exploratory factor analysis. Tutorials in quantitative methods for psychology, 9(2), 79-94. https://doi.org/10.20982/tqmp.09.2.p079

69. Zikmund, G., Babin, B. J., \& Carr, J. C. M. Griffin (2010). Business Research Method.

70. Zikmund, W. G., McLeod, R., \& Gilbert, F. W. (2003). Customer relationship management: Integrating marketing strategy and information technology. New York, NY: Wiley. 